\title{
Pengaruh Pemberian IBA dan Asal Stek Terhadap Pertumbuhan Vegetatif Kumis Kucing
}

\author{
(Effect of Giving IBA and Origin of Cuttings on Vegetative Growth of Cat Whiskers) \\ Sukma Fajari Wiraswati ${ }^{1}$ dan Kaswan Badami ${ }^{1}$ \\ ${ }^{1}$ Program Studi Agroteknologi Fakultas Pertanian Universitas Trunojoyo Madura \\ Jalan Raya Telang PO. Box 02 Kamal, Bangkalan, Madura \\ *Email korespondensi: sukmafajariwiraswati17@gmail.com
}

Diterima 25 September 2018/Disetujui 05 Februari 2019

\begin{abstract}
This study was conducted to determine the effect of administration of IBA on the origin of cuttings material on vegetative growth of plant cat whiskers. This research was carried out in the Trunojoyo Madura University Experimental Field. The time of the study was conducted in January - April 2016. This study used a Completely Randomized Design (CRD) consisting of 2 treatments, namely the origin of the cuttings and the IBA concentration. The origin of the cuttings section (A), namely A1: the base cuttings, A2: middle cuttings, and A3: cutting cuttings. The concentration of IBA (B), namely B0: 0 ppm, B1: $25 \mathrm{ppm}$, B2: $50 \mathrm{ppm}$, and B3: $100 \mathrm{ppm}$. The results showed that the origin of the cuttings section of cat whiskers and administration of IBA had a significant effect on the variable number of shoots at ages 8 to 14 (MST), shoot length at 10 to 14 (MST), leaf and stem wet weight, and leaf dry weight. root, but did not significantly affect the variables when buds appeared, the longest roots, root wet weight, and stem dry weight. The middle stem cuttings with IBA 100 ppm give the highest value for the variable shoot length. The middle stem cuttings with IBA 25 ppm gave the highest value to the variables of wet, leaf, stem, root, and dry weight of leaves, stems, and roots.
\end{abstract}

Keywords: cat whiskers, as long as cuttings section, IBA.

\section{ABSTRAK}

Penelitian ini dilakukan untuk mengetahui pengaruh pemberian IBA pada asal bahan stek terhadap pertumbuhan vegetatif tanaman kumis kucing. Penelitian ini dilaksanakan di Lahan Percobaan Universitas Trunojoyo Madura. Waktu penelitian dilakukan pada bulan Januari - April 2016. Penelitian ini menggunakan Rancangan Acak Lengkap (RAL) yang terdiri atas 2 perlakuan yaitu asal bagian stek dan konsentrasi IBA. Asal bagian stek (A), yaitu A1: stek bagian pangkal, A2: stek bagian tengah, dan A3: stek bagian pucuk. Konsentrasi IBA (B), yaitu B0: 0 ppm, B1: 25 ppm, B2: 50 ppm, dan B3: 100 ppm. Hasil penelitian menunjukkan bahwa asal bagian stek tanaman kumis kucing dan pemberian IBA berpengaruh nyata terhadap variabel jumlah tunas pada umur 8 sampai 14 (MST), panjang tunas pada umur 10 sampai 14 (MST), bobot basah daun dan batang, serta bobot kering daun dan akar, namun tidak berpengaruh nyata terhadap variabel saat muncul tunas, akar terpanjang, bobot basah akar, dan bobot kering batang. Stek batang bagian tengah dengan IBA 100 ppm memberikan nilai tertinggi terhadap variabel panjang tunas. Stek batang bagian tengah dengan IBA 25 ppm memberikan nilai tertinggi terhadap variabel bobot basah daun, batang, akar, dan bobot kering daun, batang, serta akar.

Kata Kunci: kumis kucing, asal bagian stek, IBA.

\section{PENDAHULUAN}

Kumis kucing (Orthosiphon aristatus [Blume] Miq.) merupakan salah satu tanaman obat yang berpotensi untuk dikembangkan menjadi bahan baku obat. Menurut Rukmana (1995), pada tahun 1983 ekspor kumis kucing sebanyak 3,638.617 ton naik menjadi 4,970.175 ton, dan tahun 1987 naik hingga $8,791.468$ ton. Hampir $80 \%$ produksi simplisia kumis kucing Indonesia diproduksi untuk pasaran ekspor. Tanaman kumis kucing berkhasiat sebagai obat infeksi ginjal, infeksi kandung kemih, kencing batu, encok, peluruh air seni (diuretik), serta dapat menurunkan kadar glukosa darah. Tanaman kumis kucing mengandung beberapa zat antara lain orthosiponin glikosida, minyak atsiri, sinensetin, serta garam kalium. Sinensetin berkhasiat sebagai anti bakteri, sedangkan garam kalium berkhasiat sebagai diuretik dan pelarut batu saluran kencing (Hariana, 2013).

Secara alami tanaman kumis kucing dapat menghasilkan buah. Namun di Indonesia sulit sekali ditemukan buah kumis kucing, sehingga perbanyakan tanaman ini sering dilakukan dengan cara vegetatif, yakni dengan stek batang atau cabang. Permasalahan bahan tanam yang berasal dari bagian ujung batang memiliki kandungan karbohidrat yang sedikit sehingga sulit sekali untuk 
membentuk akar, karena karbohidrat merupakan bahan dasar pembentuk akar. Sedangkan bahan tanam yang berasal dari bagian pangkal sulit berakar karena pada bagian ini umumnya terlalu tua dan kulitnya mulai mengeras, sehingga primodia akar sulit menembus dinding sel. Maka dari itu salah satu tindakan untuk memicu pertumbuhan tanaman kumis kucing dapat dilakukan dengan cara memberikan Zat Pengatur Tumbuh (ZPT).

Salah satu ZPT yang banyak digunakan oleh pemulia tanaman untuk pengakaran adalah IBA (Indole Butyric Acid). IBA lebih stabil dari pada NAA dan lebih banyak digunakan untuk induksi pengakaran pada kultur jaringan. Hasil yang diperoleh Candace et al. (2003), diketahui bahwa IBA lebih efektif daripada IAA atau auksin sintetis lainnya seperti NAA, 2,4-D, dan 2,4,5-T. Wudianto (1993) mengemukakan bahwa IBA lebih cocok untuk merangsang aktifitas perakaran, karena kandungan kimianya lebih stabil dan daya kerjanya lebih lama. IBA yang diberikan pada stek berada di tempat pemberiannya, tetapi IAA lebih mudah menyebar ke bagian lain seperti batang dan daun, sehingga menghambat perkembangan pertumbuhan pucuk, sedangkan NAA mempunyai kepekatan yang sempit, sehingga batas kepekatan yang meracuni dari zat ini sangat mendekati kepekatan optimum.

\section{METODE PENELITIAN}

Penelitian dilaksanakan pada bulan Januari - April 2016 (musim hujan) di lahan percobaan Agroteknologi Fakultas Pertanian UTM yang berada pada ketinggian $\pm 5 \mathrm{~m}$ dpl. Bahan yang digunakan adalah stek batang kumis kucing bagian pangkal, tengah, dan ujung dengan 3 (tiga) mata tunas, diameter $\pm 1 \mathrm{~cm}$ (induk bahan tanam berumur 2 tahun dari Materia Medika Batu Malang), pupuk kompos, tanah mediteran, sekam mentah, IBA $10 \%$, polybag hitam berukuran 22x $20 \mathrm{~cm}$, aquades, alkohol 95\%, insektisida, dan furadan. Percobaan menggunakan rancangan acak lengkap (RAL) non faktorial dengan 2 perlakuan yaitu asal bagian stek (A), yaitu A1: stek bagian pangkal, A2: stek bagian tengah, dan A3: stek bagian pucuk. Konsentrasi IBA (B), yaitu B0: 0 ppm, B1: 25 ppm, B2: 50 ppm, dan B3: 100 ppm. Variabel yang diamati yaitu saat muncul tunas, jumlah tunas, panjang tunas, akar terpanjang, bobot basah, dan bobot kering tanaman.

Data yang diperoleh dianalisis dengan analisis sidik ragam, jika terjadi pengaruh maka diuji lanjut dengan uji BNJ taraf $5 \%$.

\section{HASIL DAN PEMBAHASAN}

\section{Saat Muncul Tunas}

Hasil analisis sidik ragam pada variabel saat muncul tunas, menunjukkan bahwa perlakuan asal stek dan konsentrasi perndaman IBA tidak memberi pengaruh nyata terhadap saat muncul tunas (Tabel 1.).
Hal ini diduga karena IBA bukan sumber nutrisi dan tidak mempengaruhi cadangan makanan yang ada di dalam stek. Hal ini sesuai dengan pernyataan Dwijoseputro (1986), bahwa zat pengatur tumbuh adalah senyawa organik bukan hara (nutrien), yang dalam jumlah sedikit dapat mendukung, menghambat, serta dapat merubah proses fisiologi tumbuhan. Saat muncul tunas dipengaruhi oleh jumlah cadangan makanan yang terkandung di dalam stek itu sendiri, Sitompul dan Guritno (1995) menyatakan bahwa penggunaan cadangan makanan oleh stek akan menghasilkan energi dan energi yang dihasilkan tersebut dapat mendorong pecahnya kuncup dan jaringan meristem pada titik tumbuh tunas makin aktif.

\section{Jumlah Tunas}

Hasil analisis sidik ragam pada variabel jumlah tunas, menunjukkan bahwa perlakuan asal stek dan konsentrasi perendaman IBA tidak memberi pengaruh nyata pada umur 2 sampai 6 MST. Hal ini diduga karena setiap bagian stek memiliki jumlah mata tunas yang sama, yaitu 3 mata tunas, sehingga jumlah tunas yang tumbuh juga hampir seragam. Nilai rata-rata jumlah tunas (Tabel 2.), jumlah tunas tertinggi terdapat pada perlakuan A1B3, yaitu 3.89 (4 MST), dan 3.89 (6 MST), sedangkan jumlah tunas terendah terdapat pada perlakuan A3B1, yaitu 2.44 (6 MST). Hal ini sesuai dengan Hartmann dan Kester (1983) dalam Supriyanto dan Saepuloh (2014), yang menyatakan bahwa stek yang masih muda berwarna hijau dan sukulen menandakan kandungan karbohidrat yang sangat rendah namun kandungan nitrogen cukup tinggi, stek yang demikian cenderung lebih mudah mengalami pembusukan.

Pada umur 8 sampai 14 MST (Tabel 2.) menunjukkan pengaruh yang nyata. Pada umur 14 MST perlakuan A1B0 dan A1B3 berbeda nyata dengan A3B0, A3B1, A3B2, A3B3. Stek pucuk diduga terlalu muda sehingga mudah mengalami pembusukan. Agbo dan Obi (2008) dalam Supriyanto dan Saepuloh (2014) menyatakan, stek hardwood memiliki jumlah tunas yang dihasilkan lebih banyak dibandingkan stek pada softwood, hal ini diduga kandungan karbohidrat yang tinggi yang terdapat pada bahan stek hardwood berkontribusi pada pembentukan tunas.

\section{Panjang Tunas}

Hasil analisis sidik ragam menunjukkan bahwa perlakuan asal stek dan konsentrasi perendaman IBA tidak memberi pengaruh nyata pada umur 2 sampai 8 MST. Hal ini diduga hormon IBA belum menyebar ke seluruh tanaman dan akar yang terbentuk masih sedikit sehingga pertumbuhan tunas masih belum optimal. Pada umur 10 MST perlakuan A2B3 berbeda nyata dengan A1B3, sedangkan pada umur 14 MST perlakuan A2B3 berbeda nyata dengan A1B0, A1B2, A1B3. 
Tabel 1. Rata-rata saat muncul tunas (HST) pada semua perlakuan

\begin{tabular}{cc}
\hline Perlakuan & Rata-rata Saat Muncul Tunas (HST) \\
\hline A1B0 & 4.22 \\
A1B1 & 4.78 \\
A1B2 & 4.45 \\
A1B3 & 4.22 \\
A2B0 & 4.89 \\
A2B1 & 4.55 \\
A2B2 & 5.00 \\
A2B3 & 4.89 \\
A3B0 & 4.89 \\
A3B1 & 5.00 \\
A3B2 & 5.00 \\
A3B3 & 5.78 \\
\hline BNJ 5\% & - \\
\hline
\end{tabular}

Tabel 2. Rata-rata jumlah tunas (MST) pada semua perlakuan

\begin{tabular}{|c|c|c|c|c|c|c|c|}
\hline \multirow[b]{2}{*}{ Perlakuan } & \multicolumn{7}{|c|}{ Rata-rata Jumlah Tunas (MST) } \\
\hline & $\begin{array}{c}2 \\
\text { MST }\end{array}$ & $4 \mathrm{MST}$ & $6 \mathrm{MST}$ & $8 \mathrm{MST}$ & $10 \mathrm{MST}$ & $12 \mathrm{MST}$ & $14 \mathrm{MST}$ \\
\hline A1B0 & 3.22 & 3.44 & 3.78 & $3.78 \mathrm{~cd}$ & $3.78 \mathrm{~cd}$ & $3.78 \mathrm{~cd}$ & $3.78 \mathrm{~d}$ \\
\hline $\mathrm{A} 1 \mathrm{~B} 1$ & 3.00 & 3.67 & 3.78 & $3.78 \mathrm{~cd}$ & $3.78 \mathrm{~cd}$ & $3.44 \mathrm{bcd}$ & $3.44 \mathrm{bcd}$ \\
\hline $\mathrm{A} 1 \mathrm{~B} 2$ & 3.78 & 3.78 & 3.89 & $3.89 \mathrm{~d}$ & $3.89 \mathrm{~d}$ & $3.78 \mathrm{~cd}$ & $3.67 \mathrm{~cd}$ \\
\hline A1B3 & 3.56 & 3.89 & 3.89 & $3.89 \mathrm{~d}$ & $4.00 \mathrm{~d}$ & $4.00 \mathrm{~d}$ & $3.89 \mathrm{~d}$ \\
\hline $\mathrm{A} 2 \mathrm{~B} 0$ & 3.11 & 3.44 & 3.67 & $3.11 \mathrm{abcd}$ & $3.00 \mathrm{abcd}$ & $2.89 \mathrm{abcd}$ & $2.78 \mathrm{abcd}$ \\
\hline $\mathrm{A} 2 \mathrm{~B} 1$ & 3.22 & 3.33 & 3.56 & $3.44 \mathrm{bcd}$ & $3.44 \mathrm{bcd}$ & $3.33 \mathrm{bcd}$ & $3.22 \mathrm{bcd}$ \\
\hline $\mathrm{A} 2 \mathrm{~B} 2$ & 2.44 & 3.33 & 3.45 & $2.89 \mathrm{abcd}$ & $2.89 \mathrm{abcd}$ & $2.66 \mathrm{abcd}$ & $2.66 \mathrm{abcd}$ \\
\hline $\mathrm{A} 2 \mathrm{~B} 3$ & 3.00 & 2.56 & 3.00 & $2.45 \mathrm{abc}$ & $2.45 \mathrm{abc}$ & $2.45 \mathrm{abc}$ & $2.45 \mathrm{abcd}$ \\
\hline $\mathrm{A} 3 \mathrm{~B} 0$ & 2.44 & 3.34 & 3.50 & $2.00 \mathrm{a}$ & $2.11 \mathrm{ab}$ & $2.11 \mathrm{ab}$ & $2.11 \mathrm{ab}$ \\
\hline A3B1 & 2.72 & 2.83 & 2.44 & $1.89 \mathrm{a}$ & $1.78 \mathrm{a}$ & $1.78 \mathrm{a}$ & $1.67 \mathrm{a}$ \\
\hline A3B2 & 3.00 & 2.50 & 2.89 & $2.39 \mathrm{ab}$ & $2.28 \mathrm{ab}$ & $2.28 \mathrm{ab}$ & $2.17 \mathrm{ab}$ \\
\hline A3B3 & 2.83 & 3.00 & 3.17 & $2.33 \mathrm{ab}$ & $1.84 \mathrm{a}$ & $2.33 \mathrm{ab}$ & $2.22 \mathrm{abc}$ \\
\hline BNJ 5\% & - & - & - & 1.38 & 1.39 & 1.40 & 1.47 \\
\hline
\end{tabular}

Keterangan : angka-angka yang diikuti dengan huruf yang sama pada kolom yang sama menunjukkan tidak berbeda nyata berdasarkan uji BNJ $5 \%$.

Tabel 3. Rata-rata panjang tunas (MST) pada semua perlakuan

\begin{tabular}{|c|c|c|c|c|c|c|c|}
\hline \multirow{2}{*}{ Perlakuan } & \multicolumn{7}{|c|}{ Rata-rata Panjang Tunas (MST) } \\
\hline & $2 \mathrm{MST}$ & $4 \mathrm{MST}$ & $6 \mathrm{MST}$ & $8 \mathrm{MST}$ & $10 \mathrm{MST}$ & $12 \mathrm{MST}$ & $14 \mathrm{MST}$ \\
\hline A1B0 & 0.47 & 1.01 & 0.90 & 1.76 & $3.05 \mathrm{ab}$ & $4.63 \mathrm{ab}$ & $6.16 \mathrm{a}$ \\
\hline A1B1 & 0.55 & 1.10 & 1.15 & 2.07 & $3.43 \mathrm{ab}$ & $6.08 \mathrm{ab}$ & $8.63 \mathrm{ab}$ \\
\hline A1B2 & 0.44 & 1.05 & 0.98 & 1.80 & $3.03 \mathrm{ab}$ & $4.25 \mathrm{a}$ & $6.07 \mathrm{a}$ \\
\hline A1B3 & 0.55 & 0.97 & 1.29 & 1.97 & $2.81 \mathrm{a}$ & $4.30 \mathrm{a}$ & $6.08 \mathrm{a}$ \\
\hline $\mathrm{A} 2 \mathrm{~B} 0$ & 0.41 & 0.99 & 1.09 & 2.47 & $4.05 \mathrm{ab}$ & $6.44 \mathrm{ab}$ & $8.99 \mathrm{ab}$ \\
\hline $\mathrm{A} 2 \mathrm{~B} 1$ & 0.45 & 1.30 & 1.12 & 2.76 & $4.66 \mathrm{ab}$ & $7.11 \mathrm{ab}$ & $9.77 \mathrm{ab}$ \\
\hline $\mathrm{A} 2 \mathrm{~B} 2$ & 0.55 & 0.85 & 1.16 & 2.84 & $4.42 \mathrm{ab}$ & $8.00 \mathrm{~b}$ & $10.80 \mathrm{ab}$ \\
\hline A2B3 & 0.64 & 1.30 & 1.56 & 2.35 & $5.07 \mathrm{~b}$ & $8.06 \mathrm{~b}$ & $11.22 \mathrm{~b}$ \\
\hline $\mathrm{A} 3 \mathrm{~B} 0$ & 0.36 & 0.71 & 0.79 & 2.06 & $3.67 \mathrm{ab}$ & $6.23 \mathrm{ab}$ & $8.62 \mathrm{ab}$ \\
\hline A3B1 & 0.44 & 1.12 & 1.50 & 2.41 & $3.80 \mathrm{ab}$ & $5.13 \mathrm{ab}$ & $7.04 \mathrm{ab}$ \\
\hline A3B2 & 0.41 & 1.08 & 0.97 & 2.02 & $3.18 \mathrm{ab}$ & $5.24 \mathrm{ab}$ & $7.68 \mathrm{ab}$ \\
\hline A3B3 & 0.36 & 0.85 & 0.92 & 1.86 & $3.31 \mathrm{ab}$ & $5.60 \mathrm{ab}$ & $8.32 \mathrm{ab}$ \\
\hline BNJ 5\% & - & - & - & - & 2.19 & 3.67 & 4.89 \\
\hline
\end{tabular}

Keterangan : angka-angka yang diikuti dengan huruf yang sama pada kolom yang sama menunjukkan tidak berbeda nyata berdasarkan uji BNJ $5 \%$. 
Tabel 4. Rata-rata akar terpanjang $(\mathrm{cm})$ pada semua perlakuan

\begin{tabular}{cc}
\hline Perlakuan & Akar Terpanjang $(\mathrm{cm})$ \\
\hline A1B0 & 33.45 \\
A1B1 & 34.48 \\
A1B2 & 33.84 \\
A1B3 & 34.08 \\
A2B0 & 36.90 \\
A2B1 & 34.99 \\
A2B2 & 37.92 \\
A2B3 & 34.67 \\
A3B0 & 33.30 \\
A3B1 & 32.74 \\
A3B2 & 31.62 \\
A3B3 & 32.00 \\
\hline BNJ 5\% & - \\
\hline
\end{tabular}

Tabel 5. Rata-rata bobot basah daun, batang, dan akar (gram) pada semua perlakuan

\begin{tabular}{lccc} 
& Perlakuan & \multicolumn{3}{c}{ Rata-rata Bobot Basah } \\
\cline { 2 - 4 } & Daun (gram) & Batang (gram) & Akar (gram) \\
\hline A1B0 & $3.79 \mathrm{ab}$ & $1.94 \mathrm{ab}$ & 4.53 \\
A1B1 & $4.11 \mathrm{ab}$ & $2.47 \mathrm{ab}$ & 3.91 \\
A1B2 & $3.45 \mathrm{ab}$ & $1.75 \mathrm{ab}$ & 4.52 \\
A1B3 & $3.60 \mathrm{ab}$ & $1.95 \mathrm{ab}$ & 5.88 \\
A2B0 & $3.80 \mathrm{ab}$ & $2.36 \mathrm{ab}$ & 6.05 \\
A2B1 & $5.17 \mathrm{~b}$ & $3.45 \mathrm{~b}$ & 5.21 \\
A2B2 & $4.73 \mathrm{~b}$ & $2.84 \mathrm{ab}$ & 4.40 \\
A2B3 & $3.92 \mathrm{ab}$ & $2.13 \mathrm{ab}$ & 3.61 \\
A3B0 & $3.21 \mathrm{ab}$ & $1.56 \mathrm{a}$ & 2.62 \\
A3B1 & $1.99 \mathrm{a}$ & $1.02 \mathrm{a}$ & 4.17 \\
A3B2 & $3.47 \mathrm{ab}$ & $1.72 \mathrm{ab}$ & 3.73 \\
A3B3 & $3.00 \mathrm{ab}$ & $1.57 \mathrm{a}$ & - \\
\hline BNJ 5\% & 2.65 & 1.86 & - \\
\hline
\end{tabular}

Keterangan : angka-angka yang diikuti dengan huruf yang sama pada kolom yang sama menunjukkan tidak berbeda nyata berdasarkan uji BNJ 5\%.

Tabel 6. Rata-rata bobot kering daun, batang, dan akar (gram) pada semua perlakuan

\begin{tabular}{lccc} 
& Perlakuan & Rata-rata Bobot Kering & Akar (gram) \\
\cline { 2 - 4 } & Daun (gram) & Batang (gram) & $0.54 \mathrm{ab}$ \\
A1B0 & $0.73 \mathrm{ab}$ & 0.43 & $0.67 \mathrm{ab}$ \\
A1B1 & $0.84 \mathrm{ab}$ & 0.65 & $0.46 \mathrm{ab}$ \\
A1B2 & $0.59 \mathrm{ab}$ & 0.39 & $0.56 \mathrm{ab}$ \\
A1B3 & $0.63 \mathrm{ab}$ & 0.42 & $0.79 \mathrm{~b}$ \\
A2B0 & $0.88 \mathrm{ab}$ & 0.50 & $0.81 \mathrm{~b}$ \\
A2B1 & $1.09 \mathrm{~b}$ & 0.68 & $0.68 \mathrm{ab}$ \\
A2B2 & $0.97 \mathrm{~b}$ & 0.55 & $0.56 \mathrm{ab}$ \\
A2B3 & $0.73 \mathrm{ab}$ & 0.41 & $0.48 \mathrm{ab}$ \\
A3B0 & $0.63 \mathrm{ab}$ & 0.31 & $0.34 \mathrm{a}$ \\
A3B1 & $0.29 \mathrm{a}$ & 0.31 & $0.52 \mathrm{ab}$ \\
A3B2 & $0.57 \mathrm{ab}$ & 0.29 & $0.39 \mathrm{ab}$ \\
A3B3 & $0.53 \mathrm{ab}$ & 0.31 & 0.44 \\
\hline BNJ 5\% & 0.60 & - & \\
\hline Keterangn
\end{tabular}

Keterangan : angka-angka yang diikuti dengan huruf yang sama pada kolom yang sama menunjukkan tidak berbeda nyata berdasarkan uji BNJ $5 \%$. 
Jika dilihat dari nilai rata-rata panjang tunas pada (Tabel 3.) perlakuan A2B1, A2B2, A2B3 (stek batang tengah dengan IBA $25 \mathrm{ppm}, 50 \mathrm{ppm}, 100 \mathrm{ppm}$ ) memberi nilai yang lebih tinggi dari pada perlakuan stek bagian pangkal dan pucuk dengan semua konsentrasi IBA. Hal ini diduga karena adanya perbedaan tingkat kedewasaan serta pembelahan sel pada setiap bahan stek. Rochiman dan Harjadi (1973) dalam Karo (2014), menyatakan bahwa tingkat kedewasaan jaringan dari bagian tanaman yang digunakan sebagai bahan stek dan umur induk stek berpengaruh terhadap kapasitas stek untuk membentuk tunas. Menurut Adriance dan Brison (1967) dalam Suwandiyati (2009), bahwa kandungan bahan stek, terutama persediaan karbohidrat dan nitrogen sangat menentukan pertumbuhan tunas stek. Kandungan nitrogen dan karbohidrat yang seimbang akan memacu pertumbuhan tunas stek.

\section{Akar Terpanjang}

Hasil analisis sidik ragam pada menunjukkan bahwa perlakuan asal stek dan konsentrasi perendaman IBA tidak memberi pengaruh nyata terhadap akar terpanjang. Nilai rata-rata akar terpanjang yang tertinggi terdapat pada perlakuan A2B2, yaitu $37.92(\mathrm{~cm})$, sedangkan nilai rata-rata akar terpanjang yang terendah diperoleh pada perlakuan A3B2, yaitu $31.62(\mathrm{~cm})$. Hal ini diduga stek bagian tengah dengan IBA 50 ppm bisa memberikan hasil akar terpanjang yang lebih baik dari perlakuan lainnya. Penelitian Kastono et al. (2005) menyatakan bahwa, stek batang tengah mengandung karbohidrat yang lebih sedikit dari bagian pangkal, namun akar yang dihasilkan stek batang tengah lebih panjang daripada bagian pangkal. Hal ini disebabkan dinding sel batang pangkal dalam kondisi mengeras akibat terlalu tua, sehingga primodia akar sulit menembus akibatnya akar sulit terbentuk.

Pemberian IBA $50 \mathrm{ppm}$ mampu menghasilkan akar tepanjang pada stek batang tengah dari pada tanpa IBA, IBA $25 \mathrm{ppm}$, dan $100 \mathrm{ppm}$. Hal ini disebabkan karena konsentrasi IBA yang optimal untuk akar terpanjang adalah $50 \mathrm{ppm}$, dalam konsentrasi ini akar akan terdorong untuk tumbuh, sedangkan perlakuan IBA 100 ppm diduga telah melebihi nilai optimum sehingga aktivitas pemanjangan dan pembelahan sel akar mengalami penurunan. Menurut Danoesastro (1964) dalam Hasanah dan Nintya (2007), bahwa keefektifan zat tumbuh eksogen hanya terjadi pada konsentrasi tertentu. Pada konsentrasi tinggi dapat merusak, sedangkan pada konsentrasi yang terlalu rendah tidak efektif.

\section{Bobot Basah Daun, Batang dan Akar}

Hasil analisis sidik ragam menunjukkan bahwa perlakuan asal stek dan konsentrasi perendaman IBA berpengaruh nyata terhadap bobot basah daun dan batang. Kastono et al. (2005) menyatakan bahwa, bobot basah tanaman dipengaruhi oleh kandungan air dan karbohidrat di dalamnya.

Perlakuan A2B1 dan A2B2 berbeda nyata dengan A3B1. Batang tengah memiliki kandungan nitrogen lebih rendah daripada batang pucuk. Nitrogen berfungsi untuk memicu pertumbuhan tunas, sedangkan karbohidrat memicu pertumbuhan akar. Sejalan dengan pendapat Heddy (1986), bahwa pada umumnya bila kandungan karbohidrat rendah, maka kandungan protein tinggi, stek yang demikian akan lebih cepat pada proses pertumbuhan tunas.

\section{Bobot Kering Daun, Batang, dan Akar}

Hasil analisis sidik ragam menunjukkan bahwa perlakuan asal stek dan konsentrasi perendaman IBA berpengaruh nyata terhadap bobot kering daun dan bobot kering akar. Hal ini diduga pada bagian daun dan akar mengandung senyawa organik yang tinggi. Sejalan dengan pendapat Kastono et al. (2005) bahwa, berat kering tanaman mencerminkan akumulasi senyawa organik yang berhasil disintesis tanaman dari senyawa anorganik, terutama air dan karbondioksida. Unsur hara yang telah diserap akar memberi kontribusi terhadap pertambahan berat kering tanaman.

Nilai rata-rata bobot kering daun dan akar tertinggi terdapat pada perlakuan A2B1, yaitu berturut-turut 1.09 (gram) dan 0.81 (gram). Hal ini sejalan dengan penelitian Hasanah dan Nintya (2007), bahwa perlakuan IBA 25 ppm menunjukkan hasil terbaik pada berat kering tanaman nilam, dari pada perlakuan IBA 50 ppm dan 75 ppm. Kondisi ini disebabkan karena pada konsentrasi tersebut perakaran kumis kucing tumbuh optimal, sehingga air dan unsur hara yang diserap akan semakin banyak.

\section{KESIMPULAN}

Perlakuan asal bagian stek tanaman kumis kucing dan pemberian IBA berpengaruh nyata terhadap variabel jumlah tunas pada umur 8 sampai 14 (MST), panjang tunas pada umur 10 sampai 14 (MST), bobot basah daun dan batang, serta bobot kering daun dan akar, namun tidak berpengaruh nyata terhadap variabel saat muncul tunas, akar terpanjang, bobot basah akar, dan bobot kering batang.

\section{SARAN}

Untuk menghasilkan berat basah daun terbaik, disarankan menggunakan stek bagian tengah dengan IBA 25 ppm.

\section{DAFTAR PUSTAKA}

Candace, S.W., M.R. Aaron, P. Julie, K.M. Gloria. 2003. Transport of the Two Natural Auxins Indole-3Butyric Acid and Indole-3-Acetic Acid in Arabidopsis. Department of Biology, McGill University. Canada.

Dwijoseputro, D. 1986. Pengantar Fisiologi Tumbuhan. Jakarta (ID): Penerbit PT Gramedia Jakarta.

Hariana, A. 2013. 262 Tanaman Obat dan Khasiatnya. Jakarta (ID): Penebar Swadaya. 
Hasanah, F.N., N. Setiari. 2007. Pembentukan Akar pada Stek Batang Nilam (Pogostemon cablin Benth.) setelah direndam IBA (Indole Butyric Acid) pada Konsentrasi Berbeda. Buletin Anatomi dan Fisiologi. $15(2)$.

Heddy, S. 1986. Hormon Tumbuhan. Jakarta (ID): Rajawali.

Karo, M.K. 2014. Pertumbuhan Berbagai Setek Asal Tanaman Gambir (Uncaria gambir Roxb.) akibat Pemberian Berbagai Konsentrasi IBA. Jurnal Penelitian Lumbung. 13(2).

Kastono, D., H. Sawitri, Siswandono. 2005. Pengaruh Nomor Ruas Setek dan Dosis Pupuk Urea terhadap Pertumbuhan dan Hasil Kumis Kucing. Ilmu Pertanian. 12(1):56-64.

Rukmana, R. 1995. Kumis Kucing. Yogyakarta (ID): Kanisius.
Sitompul, S.M., B. Guritno. 1995. Analisis Pertumbuhan Tanaman. Yogyakarta: Gadjah Mada University Press.

Supriyanto, A. Saepuloh. 2014. Pengaruh Bahan Stek dan Hormon IBA (Indole Butryric Acid) terhadap Pertumbuhan Stek Jabon Merah (Anthocephalus macrophyllus). Jurnal Silvikultur Tropika. 5(2):104112.

Suwandiyati, N.D. 2009. Pengaruh Asal Bahan Setek dan Dosis Pupuk Kandang Sapi terhadap Pertumbuhan Bibit Nilam (Pogostemon cablin Benth.). Skripsi Program Studi Agronomi Fakultas Pertanian Universitas Sebelas Maret Surakarta.

Wudianto, R. 1993. Membuat Stek, Cangkok, dan Okulasi. Jakarta (ID): Penebar Swadaya. 